\title{
$\beta$-Aminobutyric Acid Raises Salt Tolerance and Reorganises Some Physiological Characters in Calendula officinalis L. Plant
}

\author{
E. F. Ali $^{1,2^{\star}}$ and F. A. S. Hassan ${ }^{1,3}$ \\ ${ }^{1}$ Department of Biology, Faculty of Science, Taif University, Saudi Arabia. \\ ${ }^{2}$ Department of Floriculture, Faculty of Agriculture, Assiut University, Egypt. \\ ${ }^{3}$ Department of Horticulture, Faculty of Agriculture, Tanta University, Egypt.
}

Authors' contributions

This work was carried out in collaboration between both authors. Authors EFA and FASH designed the study, performed the statistical analysis, wrote the protocol, wrote the first draft of the manuscript and managed the literature searches. Both authors read and approved the final manuscript.

Article Information

DOI: 10.9734/ARRB/2018/v30i530027

Editor(s):

(1) Dr. Jin-Zhi Zhang, Key Laboratory of Horticultural Plant Biology (Ministry of Education), College of Horticulture and Forestry Science, Huazhong Agricultural University, China.

(2) Dr. George Perry, Dean and Professor of Biology, University of Texas at San Antonio, USA.

Reviewers:

(1) Mairton Gomes da Silva, Federal University of Recôncavo of Bahia (UFRB), Brazil.

(2) Toshik larley da Silva, Federal University of Viçosa, Brazil.

(3) Manvkesh Kumar, Bihar Agricultural University, India.

Complete Peer review History: http://www.sdiarticle3.com/review-history/44349

Original Research Article

Received 08 July 2018

Accepted 26 September 2018

Published 14 March 2019

\begin{abstract}
Salt stress is one of the main factors limiting plant growth and yield globally. Seed priming technique with different chemicals including $\beta$-aminobutyric acid (BABA) is found to be effective in enhancing plant growth and development under biotic and abiotic stresses. Scarce reports have been found about BABA seed priming in medicinal plants under stress conditions; however, several studies have been conducted on other crops but have not made an in-depth study to investigate biochemical and physiological changes. In current study the shoot growth, relative water content (RWC), chlorophyll content, stomatal conductance, nutrient content ( $\mathrm{N}, \mathrm{P}, \mathrm{K}, \mathrm{Na}$ and $\mathrm{Cl}$ ), proline, malondialdehyde (MDA), hydrogen peroxide $\left(\mathrm{H}_{2} \mathrm{O}_{2}\right)$ content, antioxidants enzymes (CAT, SOD and POD), membrane stability index (MSI), total phenolic and flavonoids contents lipid peroxidation and membrane permeability were investigated in Calendula officinalis L. leaves due to BABA seed priming and/or salt stress treatment. Salt stress treatment significantly reduced the growth
\end{abstract}


characters, inflorescence number as well as its fresh and dry weights, $\mathrm{N}, \mathrm{P}$ and $\mathrm{K}$ contents in leaves, RWC, chlorophyll content, stomatal conductance, MSI and total phenolic and flavonoids contents of pot marigold. However, proline content, MDA accumulation, $\mathrm{H}_{2} \mathrm{O}_{2}$ content and antioxidant enzyme activity (CAT, SOD and POD) were increased due to salt stress. On the other hand, seed priming with BABA significantly improved the growth characters, inflorescence attributes and the previously mentioned physiological and biochemical parameters investigated relative to the control. Applying seed priming under salt stress conditions significantly mitigated the negative effects of salinity and enhanced the growth and productivity of pot marigold and therefore was suggested to be an effective technique prior to cultivation.

Keywords: Antioxidant; enzymes; flavonoids; lipid peroxidation; proline; salt stress; seed priming.

\section{INTRODUCTION}

Pot marigold or marigold (Calendula officinalis L.) is a medicinal herb belonging to the Asteraceae family, which is widely used in traditional medicine [1]. Marigold contains two classes of pigments (flavonoids and carotenoids) therefore, it can be used as a colourant, which may be used as orange and yellow natural colours. Natural colours are gaining great attention since several synthetic colourants have given rise to allergic, toxic and carcinogenic effects [2,3]. Moreover, flavonoids have antioxidant activities, which play a considerable role in human health and food preservation by resisting damage caused by the oxidising agent. It has been also that marigold plants reported possessing several pharmacological activities including, antiinflammatory [4], antioxidant [5], antifungal [6], antibacterial [7], antiviral [8] and wound healing activity [9].

Abiotic stress is one of the major factors limiting plant growth and yield globally. Salt stress is utmost environmental challenge affecting sorely plant growth and production. Salinisation is a considerable problem for different areas around the world that renders prohibitive growth and crop production [10]. The prejudicial effects of salt on plants growth are connected to ionic, osmotic and oxidative stresses [11]. Ionic component of salinity is associated with toxicity of particular ionic species (e.g. $\mathrm{Na}^{+}$or $\mathrm{Cl}^{-}$stress) to plants as well as a nutrient imbalance. $\mathrm{NaCl}$ decreased fresh and dry masses, relative growth rate, and $\mathrm{K}^{+}$and $\mathrm{Ca}^{2+}$ content but it increased $\mathrm{Na}^{+}$content and $\mathrm{Na}^{+} / \mathrm{K}^{+}$ratio $[12,13]$.

High soil salt concentration decrease soil water potential resulting in water deficit or osmotic stress. Salt stress also induces fashioning superoxide anion, singlet oxygen, hydroxyl radical and hydrogen peroxide $\left(\mathrm{H}_{2} \mathrm{O}_{2}\right)$ and hence causes oxidative stress in several plants [14].
Salinised plants evidenced a decreasing in plant growth characters such as shoot length, root length, fresh and dry weights as well as the contents of photosynthetic pigments (chlorophyll $a$ and $b$, and carotenoids) and the activity of catalase (CAT) against control plants $[15,16]$.

Salt stress resulted in significant changes in macro and micronutrients content and sugars [10]. Salinity stress triggered a concentrationdependent overproduction of reactive oxygen species (ROS) and a concurrent up-regulation of the expression of different antioxidants $[17,18]$. The promotion in ROS production resulted in oxidative stress in plants [19]. $\mathrm{NaCl}$ treatment significantly increased ROS and malondialdehyde (MDA) content, and electrolyte permeability in several species $[20,21,22,23$, 24,25].

MDA content is a sign of membrane damage at the cellular level in stressed plants [26]. Subsequently, MDA accumulation can avail as an important oxidative stress index [27]. In contrast, salinity stress boosted the contents of several organic solutes (soluble protein, soluble sugar, proline and total free amino acids), malondialdehyde (MDA), ascorbic acid and $\mathrm{Na}$, as well as the activities of superoxide dismutase (SOD), peroxidase (POD), and ascorbate peroxidase (APX) in stressed plants relative to lupine control plants [16,24,28].

There are scarce efforts to ameliorate salt stress of medicinal plants by traditional breeding programs, but few successes have been reported. Increasing the toleration of these plants to salt or developing tolerance species by exogenous application of different treatments is therefore imperative. The germination of seed and the growth of seedling are the two critical periods for the establishment of crops [29]. These stages are the most sensitive to abiotic stress [30]. Jisha and Puthur [31,32] reported 
that seed priming is low cost, easy and low-risk technique for enhancing growth and development particularly, in plants grown under reverse environmental conditions. The priming treatments by natural and/or synthetic compounds resulted in the inducement of physiological state in plants. Seed priming enhanced seed performance, expands faster and coincided germination with definite biochemical, physiological, cellular and molecular changes $[28,33,34,35,36]$. These changes involve elongation and cell division, plasma membrane fluidity, the induction of stress-responsive proteins, changes in transcriptome and proteome, $\mathrm{H}^{+}$-ATPase activity $[37,38,39]$ and changes in the activity of antioxidant enzymes system $[28,39,40,41]$.

Seed priming has been shown to neutralise the adverse effects of different abiotic stress $[42,43,44]$. The priming of seeds has been proved to be a successful approach to enhance crop plants salt alleviating $[44,45,46,47]$. Moreover, different materials or chemicals were utilised in seed-priming technique from time to other, such $\beta$-aminobutyric acid (BABA), $\mathrm{KCl}, \mathrm{Si}$ and $\mathrm{CaCl}_{2}$, are usually used for the seed priming techniques $[48,49,50]$. One of these chemicals is BABA; it is a non-protein amino acid and is an isomer of naturally occurring non-protein amino acid called $y$-aminobutyric acid (GABA). BABA is a synthetic compound [51,52] and its natural occurrence is scarce. Interestingly, when BABA was applied exogenously, it was seen to play a considerable role in increasing plant tolerance versus both biotic and abiotic stresses like salt, drought and heat shock [53]. The priming with BABA gains greater attention as a priming agent. However, although Vijayakumari et al. [54] reported that the promoted effect of BABA on plants metabolism is may be due to a potentiation of natural defence mechanisms against abiotic stresses, the accurate mode of action of priming with BABA in plants is yet a mystery, though it prominence as signalling molecules during stress is un-doubtful.

Seed priming by BABA increased proline content and antioxidant enzyme activities of stressed Oryza sativa plants [55], induced a major reorganisation in solute content of flax (Linum usitatissimum) leaves which resulted in increased accumulation of carbohydrates and proline contents, a decrease in inorganic solutes and induced reduce in osmotic potential and a change in water status of leaves [56]. Moreover, $\mathrm{BABA}$ priming significantly reduced MDA content in rice seedlings and also enhanced the activity of nitrate reductase enzyme and activities of antioxidant enzymes like guaiacol peroxidase and superoxide dismutase [31]. Although BABA priming effects on abiotic stress tolerance of different plants have been investigated, there are little reports with concern to different medicinal plants. Furthermore, most of the earlier studies concerning other crops have not made an indepth study of biochemical and physiological changes correlated with the abiotic stress of the particular plants exhibited to BABA priming.

To best of our knowledge, no information on how BABA treatment regulates physiological/ biochemical processes of marigold plants subjected salt stressed. Therefore, this study is an attempt to ameliorate salt stress of this plant using non-protein amino acid (i.e. BABA) especially the mechanisms involved in this tolerance are still poorly understood.

\section{MATERIALS AND METHODS}

\subsection{Plant Materials and Treatments}

Pot marigold (Calendula officinalis L.) was used in the current study as the plant material. Uniform sizes of healthy seeds were selected for seed priming treatment. Seeds were prewashed with Triton X-100 (0.25\%) for $1 \mathrm{~min}$ to remove uncleanness. Thereafter, seeds were washed twice with distilled water for 2 min and surfacedried. The seeds were kept under shade at $25^{\circ} \mathrm{C}$ for $48 \mathrm{~h}$ to achieve the content of original moisture [31]. After washing, the seeds were divided into four groups; group one was presoaked in distilled water for $12 \mathrm{~h}$ (non-primed seeds as a control). Group two was presoaked in $1.5 \mathrm{mM} \beta$-aminobutyric acid (BABA) for $12 \mathrm{~h}$ in screw cap bottle as seed priming treatment. The BABA concentration was selected from a preliminary experiment. Group three was presoaked in distilled water for $12 \mathrm{~h}$ and was prepared for salt stress treatment after 45 days from planting. The last group was firstly primed with BABA for $12 \mathrm{~h}$ and plants raised from primed seeds were exposed to salt stress treatment. Therewith, seeds were cultivated in pots $(30 \mathrm{~cm})$ containing soil mixture (sand: peat: clay; 1:1:1) that was previously wet with tap water. All pots were irrigated with tap water and maintained under greenhouse condition. After 45 days from planting, the plants raised from the third and fourth groups were exposed to salt stress with $\mathrm{NaCl}$ at $8 \mathrm{dS} \mathrm{m}^{-1}$ at three days intervals, and the soil was washed with tap water 
every week to prevent salt accumulation during the four weeks treatment period. The salt stress concentration was selected from a preliminary investigation. Control and primed seeds (first and second groups) were irrigated by tap water every 3 days. The experiments were carried out in complete randomised design, and each treatment was replicated 4 times, and each replicate consists of 5 pots.

\subsection{Experimental Site and Growth Conditions}

This experiment was conducted at the greenhouse of Faculty of Science, Taif University, Saudi Arabia $\left(21^{\circ} 26^{\prime} 02.4 " \mathrm{~N}\right.$ 40²9'36.9"E) during September - December 2016 and was repeated in 2017 at the same conditions. The experimental site is located at an altitude of $1200 \mathrm{~m}$ having a temperate mild climate. The average temperature, relative humidity and rainfall were $20.9^{\circ} \mathrm{C}, 35-57$ and $14.84 \mathrm{~mm}$, respectively during the study.

The physical and chemical characteristics of the soil used in this study were $77.08,7.42$ and $16.50 \%$ of sand, silt and clay, respectively; $\mathrm{pH}=$ 7.85; $\mathrm{EC}=2.16 \mathrm{dSm}^{-1} ; \mathrm{OM}=0.19 \% ; \mathrm{Na}^{+}=3.26$ meq L $\mathrm{L}^{-1} \mathrm{SO}_{4}^{-2}=48.87 \mathrm{meqL}^{-1} ; \mathrm{Cl}^{-}=0.58 \mathrm{meqL}^{-}$ 1; $\mathrm{HCO}_{3}=2.07 \mathrm{meqL}^{-1}$; total $\mathrm{N}^{+}, \mathrm{PO}_{4}^{-3}$ and $\mathrm{K}^{+}$of $0.31,0.051$ and $0.062 \%$, respectively.

\subsection{Investigated Growth Characters}

Plant height $(\mathrm{cm})$, branch number, herb fresh ( $\mathrm{g}$ plant $\left.^{-1}\right)$ and dry weights (g plant $\left.{ }^{-1}\right)$ were determined by the end of the experiment. For leaf area determination $\left(\mathrm{cm}^{2}\right)$, blade area was measured using digital image analysis according to Matthew et al. [57] method. The leaf blade digital image was created in digital format using a Hewlett- Packard scanner (Hewlett Packard, Cupertino, ca), image was scanned at dot/inch (100 dpi), the blade area was measured using public domain software.

\subsection{Assessment of Inflorescence Attributes}

During the flowering period, total inflorescence number was recorded and weighted to obtain the total inflorescence fresh weight $\left(\mathrm{g} \mathrm{plant}^{-1}\right)$ and then oven dried at $70^{\circ} \mathrm{C}$ for $24 \mathrm{~h}$ to determine the inflorescence dry weight (g plant $\left.{ }^{-1}\right)$. At the flowering stage, the samples were taken for subsequent physiological and biochemical investigations.

\subsection{Relative Water Content (RWC)}

The following relationship as described by Weatherley [58] was used for leaf midday relative water content determination and calculation:

$\left(W_{\text {fresh }}-W_{\text {dry }}\right) /\left(W_{\text {turgid }}-W_{\text {dry }}\right) \times 100$, where $W_{\text {fresh }}$ is the sample fresh weight, $W_{\text {turgid }}$ is the sample turgid weight after saturating with distilled water for $24 \mathrm{~h}$ at $4^{\circ} \mathrm{C}$, and $\mathrm{W}_{\text {dry }}$ is the oven-dry $\left(70^{\circ} \mathrm{C}\right.$ for $\left.48 \mathrm{~h}\right)$ weight of the sample.

\subsection{Chlorophyll and Carotenoids Contents}

Leaf samples were isolated randomly for chlorophyll determination. Extraction in acetone was repeated until all pigments extracted. The absorbance of extracts was determined according to Sadasivam and Manickam [59]. They were measured by using spectrophotometer at wavelength of $663 \mathrm{~nm}$ for chlorophyll (a), $644 \mathrm{~nm}$ for chlorophyll (b).

\subsection{Stomatal Conductance}

Stomatal conductance (mol $\mathrm{H}_{2} \mathrm{O} \mathrm{m} \mathrm{m}^{-2} \mathrm{~s}^{-1}$ ) was determined in pot marigold leaves using Delta $\mathrm{T}$ AP4 leaf porometer, UK.

\subsection{Proline Content}

For free proline determination, the method described by Bates et al. [60] was used. Frozen leaf tissue $(0.5 \mathrm{~g})$ was homogenised with $10 \mathrm{~mL}$ of $3 \%$ sulfosalicylic acid at $4^{\circ} \mathrm{C}$. Then, the obtained extract was filtered with Whatman No. 2. Mixture of $2 \mathrm{~mL}$ of the filtrate, $2 \mathrm{~mL}$ of acidninhydrin, and $2 \mathrm{~mL}$ of glacial acetic acid was mixed in a test tube and incubated at $100^{\circ} \mathrm{C}$ for 1 $\mathrm{h}$. The reaction was terminated on the ice, and the reaction mixture then extracted with $4 \mathrm{~mL}$ of toluene. The chromophore-containing toluene was separated from the hydrated phase. The absorbance at 520 nm was spectrophotometrically determined with toluene as the blank. The proline concentration was calculated based on a standard curve and was expressed as $\mu \mathrm{mol} \mathrm{g} \mathrm{g}^{-1} \mathrm{FW}$.

\subsection{Hydrogen Peroxide $\left(\mathrm{H}_{2} \mathrm{O}_{2}\right)$ Content}

The content of $\mathrm{H}_{2} \mathrm{O}_{2}$ in leaves tissue was assayed according to Patterson et al. [61] method with little modifications. $0.5 \mathrm{~g}$ of leaves 
were homogenised with $6 \mathrm{~mL}$ of chilled $100 \%$ acetone and centrifuged at $12,000 \times \mathrm{g}$ for $10 \mathrm{~min}$ at $4^{\circ} \mathrm{C}$. The obtained extracted solution $(1 \mathrm{~mL})$ was mixed with $0.1 \mathrm{~mL}$ of $5 \% \mathrm{Ti}\left(\mathrm{SO}_{4}\right)_{2}$ and 0.2 $\mathrm{mL}$ of concentrated $\mathrm{NH}_{4} \mathrm{OH}$ solution. The titanium-peroxide complex precipitated, and this sediment was dissolved in $4 \mathrm{~mL}$ of $2 \mathrm{M} \mathrm{H}_{2} \mathrm{SO}_{4}$ after centrifugation at $3000 \times \mathrm{g}$ for $10 \mathrm{~min}$. The absorbance of the titanium-peroxide complex was monitored at $412 \mathrm{~nm}$. Finally, the absorbance was calibrated to a standard curve generated using known concentrations of $\mathrm{H}_{2} \mathrm{O}_{2}$ and was recorded calculated as $\mu \mathrm{mol} \mathrm{g}{ }^{-1}$.

\subsection{Malondialdehyde Determination (MDA)}

Leaf MDA content was spectrophotometrically measured by the method of Hodges et al. [62]. The concentration of MDA was estimated by using the formula: $M D A$ content $=6.45 \times\left(A_{532}-\right.$ $\left.A_{600}\right)-0.56 \times A_{450}$, where $A_{450}, A_{532}$ and $A_{600}$ are the absorbance at 450, 532 and $600 \mathrm{~nm}$, respectively and will be expressed as $\mu \mathrm{mol} \mathrm{mL} \mathrm{L}^{-1}$.

\subsection{Membrane Stability Index (MSI)}

MSI was determined by the method of Sairam et al. [63]. Two leaf samples $(0.2 \mathrm{~g})$ were taken and placed in $20 \mathrm{~mL}$ of double distilled water in two different $50 \mathrm{~mL}$ flasks. The first one was kept at $40^{\circ} \mathrm{C}$ for $30 \mathrm{~min}$ while the second one will be kept at $100^{\circ} \mathrm{C}$ in a boiling water bath for $15 \mathrm{~min}$. The electric conductivity of the first $\left(C_{1}\right)$ and second $\left(\mathrm{C}_{2}\right)$ samples was measured with a conductivity meter. The leakage of ions was expressed as the membrane stability index according to the following formula, MSI = [1$\left.\left(\mathrm{C}_{1} / \mathrm{C}_{2}\right)\right] \times 100$.

\subsection{Antioxidant Enzyme Activity}

Antioxidant enzyme activity was determined as the method previously described by Hassan and Mahfouz [64]. The resulting supernatant was used as an enzyme extract to determine superoxide dismutase (SOD), catalase (CAT) and peroxidase (POD) activities. Soluble protein contents of the enzyme extract were assayed according to the method of Bradford [65].

SOD (Ec 1.15.1.1) activity was assayed by measuring its ability to inhibit the photochemical reduction of nitroblue tetrazolium (NBT). SOD activity was expressed as SOD units $\mathrm{min}^{-1} \mathrm{mg}^{-1}$ protein. One unit of SOD was considered to be the amount of enzyme required to inhibit NBT reduction by $50 \%$ as described by Giannopolitis and Ries [66] by measuring the absorbance at $560 \mathrm{~nm}$ by a spectrophotometer.

CAT (Ec 1.11.1.6) activity was spectrophotometrically estimated by the method of Clairbone [67], following the disappearance of $\mathrm{H}_{2} \mathrm{O}_{2}$ at $240 \mathrm{~nm}$. The level of enzyme activity was expressed as $\mu \mathrm{mol} \mathrm{min} \mathrm{mg}^{-1}$ protein.

POD (Ec 1.11.1.7) activity was tested according to Shanon et al. [68]. Sodium acetate buffer $(0.1 \mathrm{M})$ and $0.5 \%$ guaiacol were added to the enzyme extract. The reaction was started with $0.1 \% \mathrm{H}_{2} \mathrm{O}_{2}$. The rate of change in absorbance was spectrophotometrically measured at $470 \mathrm{~nm}$, and the level of enzyme activity was expressed as $\mu \mathrm{mol} \mathrm{min}^{-1} \mathrm{mg}^{-1}$ protein.

\subsection{Total Phenol Content}

Samples of $1 \mathrm{~g}$ powder from dry inflorescences were stirred with $50 \mathrm{~mL}$ of methanol (80\%) at room temperature for $48 \mathrm{~h}$. The extract was kept below $4^{\circ} \mathrm{C}$ after removing the solvent, and the amount of total phenol content was assayed as reported by McDonald et al. [69]. The flower diluted extract $\left(0.5 \mathrm{~mL}\right.$ of $\left.1: 10 \mathrm{~g} \mathrm{~mL}^{-1}\right)$ or standard phenolic compound (gallic acid) was mixed with the Folin-Ciocalteu reagent $(5 \mathrm{~mL}$, 1:10 diluted with distilled water) and aqueous $\mathrm{Na}_{2} \mathrm{CO}_{3}(4 \mathrm{~mL}, 1 \mathrm{M})$. The total phenol content was spectrophotometrically determined at 765 $\mathrm{nm}$ and measured as gallic acid equivalent per gram of plant extract (mg GAE g ${ }^{-1} \mathrm{DW}$ ).

\subsection{Flavonoids Content}

The inflorescence flavonoids content was spectrophotometrically measured as described by Dewanto et al. [70]. Initially, $5 \% \quad \mathrm{NaNO}_{2}$ solution was added to each test tube; after five minutes, $10 \% \mathrm{AlCl}_{3}$ solution was added followed by $1.0 \mathrm{M} \mathrm{NaOH}$. The absorbance of resulting coloured solutions was recorded at $510 \mathrm{~nm}$ against the blank (distilled water). Flavonoids content was expressed as $\mathrm{mg}$ catechin equivalent per $\mathrm{g}$ fresh weight ( $\mathrm{mg} \mathrm{CE} \mathrm{g}^{-1} \mathrm{FW}$ ).

\subsection{Leaf Nutrient Contents}

The wet digestion procedure for the dried sample (0.5 g) was performed using sulphuric and perchloric acids method to determine nutrient content according to Jackson [71]. Nitrogen 
percentage in leaves was determined in the digestion using the micro-Kjeldahl method [72]. Phosphorus, potassium, sodium and chloride contents were determined as described by Jackson [70] and Johnson and Ulrich [73].

\subsection{Statistical Analysis}

The results of this study were combined for the two experiments $(n=8)$ and analysis of variance (ANOVA) was performed. SPSS 13.3 program was used for data analysing to compare means by Duncan multiple range test at $p=0.05$ level.

\section{RESULTS}

\subsection{Growth Characters}

The growth characters of pot marigold were significantly reduced in salt stress treatment since the shortest plants, lowest branch number, lowest leaf area, lightest fresh and dry weights were recorded when $\mathrm{NaCl}$ at $8 \mathrm{dS} \mathrm{m}^{-1}$ was applied (Table 1). On the other hand, seed priming with BABA significantly improved the growth characters relative to the control. Moreover, applying seed priming treatment under salt stress conditions significantly mitigated the negative effects of salinity and enhanced the growth characters. The branch number, leaf area and dry weight of plants raised from primed seeds and grown under salinity were increased by $40.52, \quad 35.61$ and $12.06 \%$, respectively compared with plants exposed to salt stress only.

\subsection{Inflorescence Yield Attributes}

Seed priming with BABA significantly enhanced inflorescence number as well as its fresh and dry weights. However, a significant retardant in these characters was observed under salt stress treatment relative to the control (Table 2). BABA seed priming led to a prominent increase of inflorescence attributes when plants were exposed to salt stress. The inflorescence number, inflorescence fresh weight and inflorescence dry weight were increased by $75.95,131.21$ and $156.38 \%$, respectively relative to salt stress treatment when seeds were primed with BABA, and then plants were grown under salt stress condition.

Table 1. Effects of seed priming with $\beta$-aminobutyric acid (BABA) on plant height, branch number per plant, leaf area, herb fresh and dry weights of Calendula officinalis L. grown under salt stress conditions

\begin{tabular}{|c|c|c|c|c|c|}
\hline Treatments & $\begin{array}{l}\text { Plant height } \\
\text { (cm) }\end{array}$ & $\begin{array}{l}\text { Branch } \\
\text { number per } \\
\text { plant }\end{array}$ & $\begin{array}{l}\text { Leaf area } \\
\left(\mathrm{cm}^{2}\right)\end{array}$ & 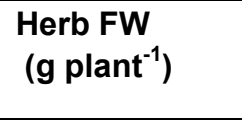 & $\begin{array}{l}\text { Herb DW } \\
\left(\text { g plant }^{-1}\right)\end{array}$ \\
\hline Control & $32.62 \pm 0.83 b$ & $11.02 \pm 0.56 b$ & $7.63 \pm 0.25 b$ & $692.36 \pm 2.87 b$ & $163.18 \pm 1.27 b$ \\
\hline Priming & $37.26 \pm 0.97 a$ & $12.84 \pm 0.42 a$ & $8.86 \pm 0.32 a$ & $723.41 \pm 1.98 a$ & $171.36 \pm 1.48 a$ \\
\hline $\mathrm{NaCl}$ stress & $21.87 \pm 0.74 d$ & $7.23 \pm 0.54 d$ & $5.42 \pm 0.28 c$ & $589.58 \pm 2.14 d$ & $136.24 \pm 1.35 d$ \\
\hline $\begin{array}{l}\text { Priming }+ \\
\mathrm{NaCl} \text { stress }\end{array}$ & $30.39 \pm 0.72 c$ & $10.16 \pm 0.58 c$ & $7.35 \pm 0.36 b$ & $654.25 \pm 2.39 c$ & $152.68 \pm 1.56 c$ \\
\hline
\end{tabular}

Table 2. Effects of seed priming with $\beta$-aminobutyric acid (BABA) on flower yield attributes of Calendula officinalis L. grown under salt stress conditions

\begin{tabular}{|c|c|c|c|}
\hline Treatments & $\begin{array}{l}\text { Inflorescences } \\
\text { number per plant }\end{array}$ & $\begin{array}{l}\text { Inflorescences FW } \\
\left.\text { (g plant }^{-1}\right)\end{array}$ & $\begin{array}{l}\text { Inflorescences } \\
\text { DW }\left(g_{\text {plant }}^{-1}\right)\end{array}$ \\
\hline Control & $12.89 \pm 0.62 b$ & $20.52 \pm 0.53 b$ & $5.69 \pm 0.21 b$ \\
\hline Priming & $15.36 \pm 0.54 a$ & $26.14 \pm 0.54 a$ & $7.54 \pm 0.27 a$ \\
\hline $\mathrm{NaCl}$ stress & $4.32 \pm 0.45 d$ & $9.69 \pm 0.56 d$ & $2.15 \pm 0.26 d$ \\
\hline Priming $+\mathrm{NaCl}$ stress & $9.12 \pm 0.43 c$ & $17.24 \pm 0.62 c$ & $4.08 \pm 0.34 c$ \\
\hline
\end{tabular}




\subsection{Leaf Nutrient Contents}

Data in Table 3 clearly show that the contents of $\mathrm{N}, \mathrm{P}$ and $\mathrm{K}$ were significantly reduced due to salinity stress relative to the control. Seed priming with BABA improved the contents of those elements in pot marigold leaves. Applying seed priming under salt stress conditions considerably increased the content of investigated macro-elements compared with saltstressed plants. Although $\mathrm{Na}$ and $\mathrm{Cl}$ contents were increased when salt stress treatment was applied, seed priming significantly decreased the content of both elements when interacted with salinity treatment. Hence, application of seed priming under salt stress treatment enhanced the $\mathrm{Na} / \mathrm{K}$ ratio and reached to 0.77 compared with 0.68 that observed in plants grown under salt stress.

\subsection{Relative Water Content (RWC)}

The treatment of salt stress significantly decreased the RWC while seed priming with BABA maintained it whether it was solely applied or even under salinity (Fig. 1A). The lowest RWC was recorded by $\mathrm{NaCl}$ stress treatment, however, seed priming suppressed this reduction and increased the RWC when interacted with salts stress application.

\subsection{Chlorophyll Content}

Salt stress treatment significantly decreased the total chlorophyll content relative to the control or seed priming treatments. However, the application of BABA seed priming significantly ameliorated the negative effects of salinity and therefore retarded the chlorophyll decrease under salt stress condition (Fig. 1B). The total chlorophyll content was increased by $41.56 \%$ due to seed priming application under salinity relative to salt stress treatment.

\subsection{Stomatal Conductance}

The stomatal conductance was considerably decreased under salt stress. However, seed priming application with BABA significantly improved the stomatal conductance in pot marigold leaves grown under salinity (Fig. 1C).

\subsection{Proline Content}

The proline content in pot marigold leaves was significantly enhanced in salt-stressed plants. Application of seed priming treatment solely did not cause any increase in proline content compared to the control. However, when seed priming was applied before salt stress treatment, a considerable increase in proline accumulation was observed (Fig. 2A).

\subsection{Malondialdehyde Content (MDA)}

Data presented in Fig. 2B indicated that MDA accumulation was significantly increased in saltstressed plants compared with priming or untreated control. Priming treatment significantly reduced the MDA content relative to the power. The impact of priming treatment in MDA reduction was very clear when it was applied under salt stress conditions since priming treatment decreased MDA by $98.95 \%$ relative to the salt stress treatment.

\subsection{Hydrogen Peroxide $\left(\mathrm{H}_{2} \mathrm{O}_{2}\right)$ Content}

The content of $\mathrm{H}_{2} \mathrm{O}_{2}$ in pot marigold leaves was significantly increased in plants grown under salt stress relative to the control. On the other hand, seed priming application significantly reduced $\mathrm{H}_{2} \mathrm{O}_{2}$ content compared to salt stress or even untreated plants. When seed priming was applied prior to cultivation and plants exposed to salt stress, the priming treatment retarded the increase in $\mathrm{H}_{2} \mathrm{O}_{2}$ that observed in salt-stressed plants (Fig. 2C).

Table 3. Effects of seed priming with $\beta$-aminobutyric acid (BABA) on leaf nutrient elements ( $\mathrm{mg} \mathrm{g}^{-1} \mathrm{DW}$ ) of Calendula officinalis, $\mathrm{L}$ grown under salt stress conditions

\begin{tabular}{|c|c|c|c|c|c|}
\hline Treatments & $\mathbf{N}$ & $\mathbf{P}$ & $\mathbf{K}$ & $\mathrm{Na}$ & $\mathrm{Cl}$ \\
\hline Control & $20.27 \pm 0.73 b$ & $3.49 \pm 0.38 b$ & $16.24 \pm 0.52 b$ & $1.98 \pm 0.28 c$ & $2.98 \pm 0.32 \mathrm{c}$ \\
\hline Priming & $22.53 \pm 0.82 a$ & $3.73 \pm 0.52 a$ & $19.26 \pm 0.54 a$ & $1.96 \pm 0.14 c$ & $2.94 \pm 0.28 c$ \\
\hline $\mathrm{NaCl}$ stress & $13.37 \pm 0.75 d$ & $2.06 \pm 0.51 d$ & $10.47 \pm 0.57 d$ & $4.63 \pm 0.23 a$ & $6.78 \pm 0.36 a$ \\
\hline $\begin{array}{l}\text { Priming }+\mathrm{NaCl} \\
\text { stress }\end{array}$ & $17.63 \pm 0.82 \mathrm{c}$ & $2.99 \pm 0.41 \mathrm{c}$ & $14.56 \pm 0.62 c$ & $2.52 \pm 0.17 b$ & $3.25 \pm 0.27 b$ \\
\hline
\end{tabular}




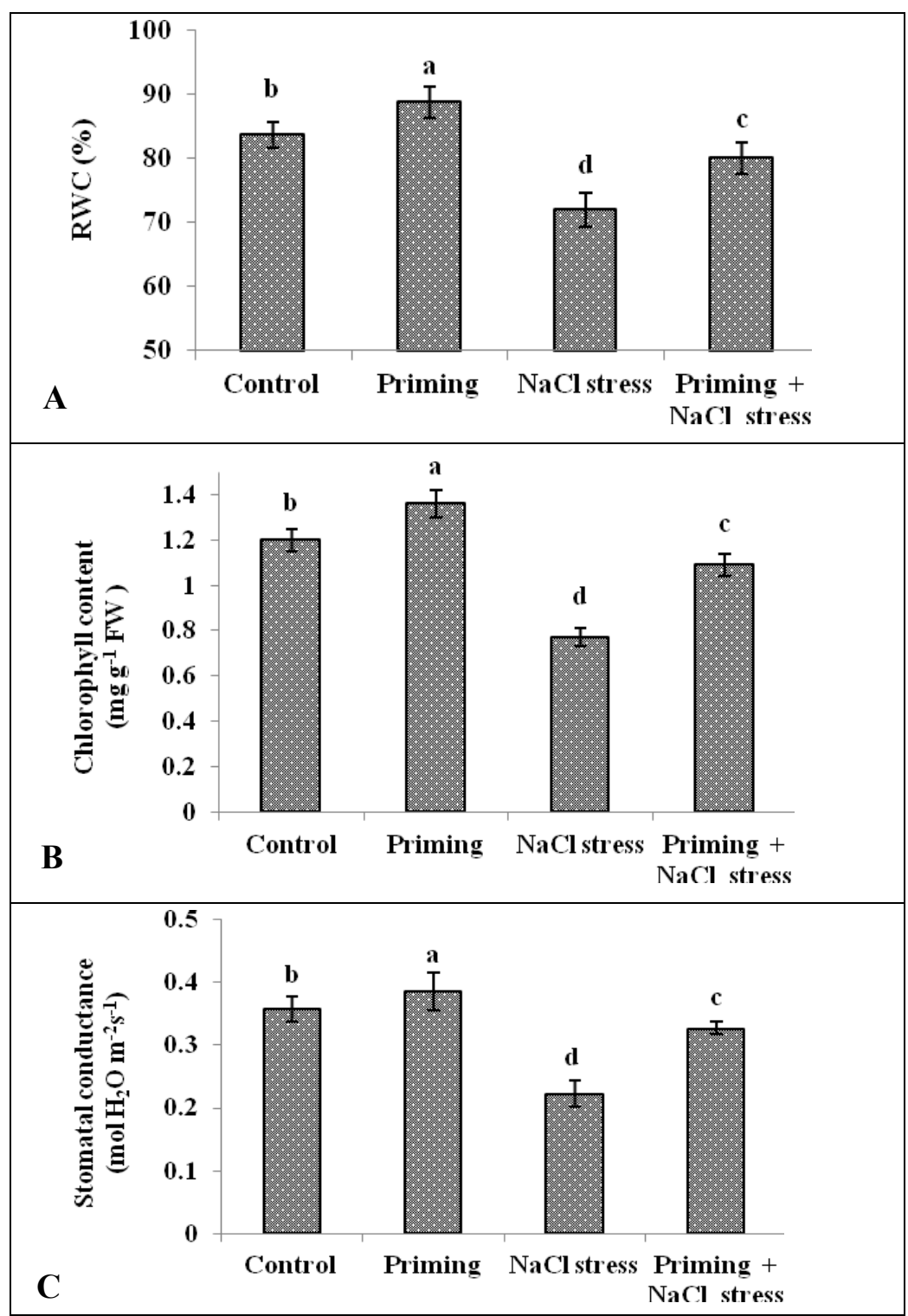

Fig. 1. Relative water content (A), chlorophyll content (B) and stomatal conductance (C) of Calendula officinalis $L$. in response to $\beta$-aminobutyric acid seed priming under salt stress conditions

Columns (means $\pm S E, n=8$ ) had different letters show a significant difference at $P \leq 0.05$

\subsection{Membrane Stability Index (MSI)}

It is very clear from the data in Fig. 2D that salt stress treatment significantly decreased the MSI relative to priming or control treatments since the lowest value of $\mathrm{MSI}$ was observed in pot marigold leaves applied with salt stress. However, the highest value of MSI was observed in plants raised from primed seeds. Additionally, priming treatment mitigated the effects of salinity and enhanced the MSI when it was applied under salinity.

\subsection{Antioxidant Enzyme Activity}

Data in Fig. 3 revealed that the antioxidant enzyme activity (CAT, SOD and POD) were significantly increased due to salt stress treatment compared to the control or priming treatments. The enzyme activity was also increased due to priming treatment relative to the control. The highest activities of assessed enzymes were recorded when priming treatment was combined with salt stress. 
Ali and Hassan; ARRB, 30(5): 1-16, 2018; Article no.ARRB.44349

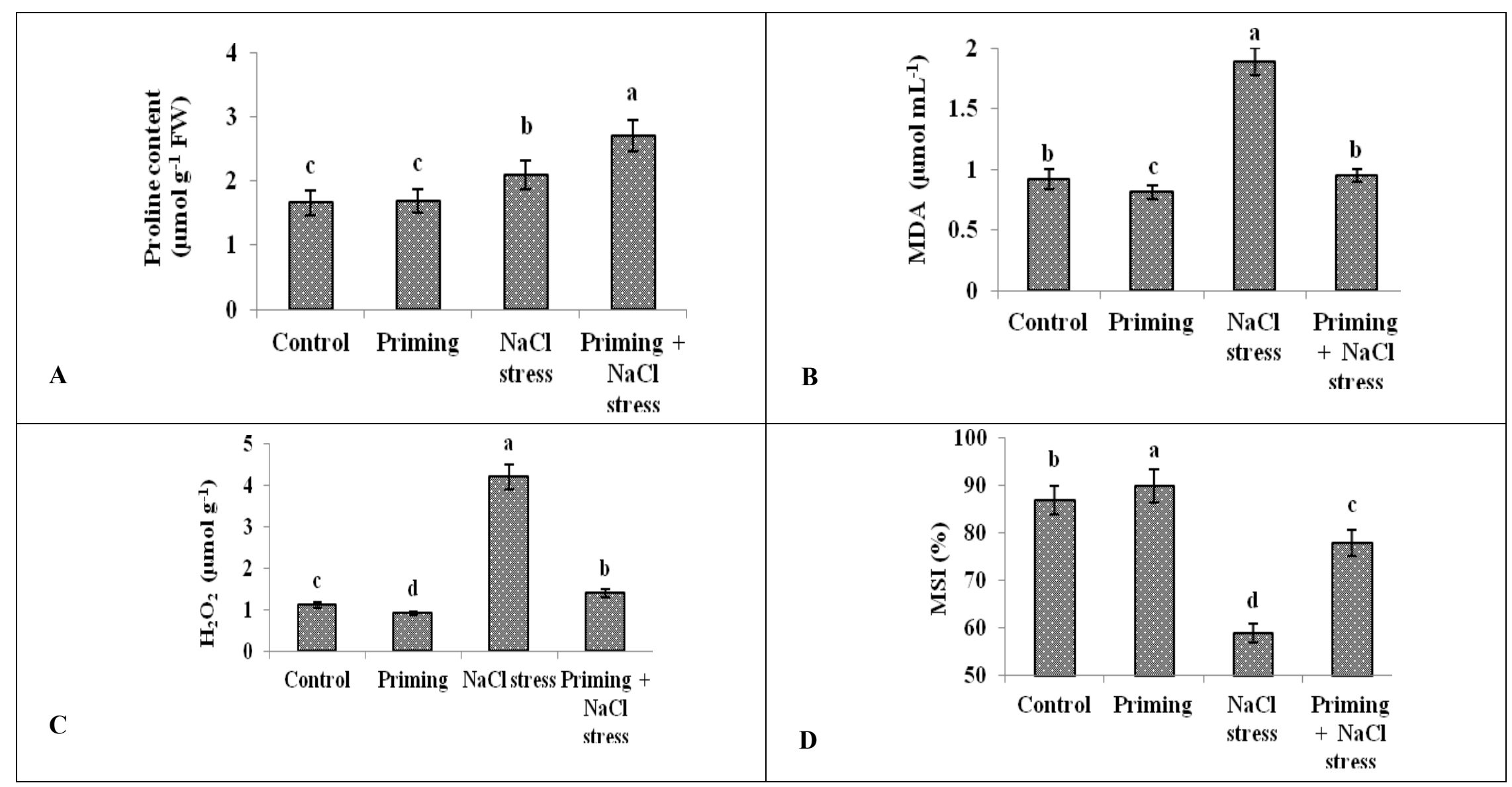

Fig. 2. Proline content (A), malondialdehyde (B), $\mathrm{H}_{2} \mathrm{O}_{2}$ content (C) membrane stability index (D) of Calendula officinalis L. in response to $\beta$ aminobutyric acid seed priming under salt stress conditions

Columns (means $\pm S E, n=8$ ) had different letters show a significant difference at $P \leq 0.05$ 


\subsection{Total Phenolic and Flavonoids Contents}

Salt stress treatment significantly reduced both total phenolic and flavonoids contents in pot marigold inflorescence compared to the control. On the other hand, both parameters were considerably increased by seed priming with BABA. Seed priming treatment alleviated the adverse effect of salinity when applied in combination with salt stress treatment and gave higher values of total phenolic and flavonoids contents relative to plants raised from salt stress only (Fig. 4). Moreover, the recorded values obtained from the combined treatment of seed priming and salinity were insignificant compared to the control.

\section{DISCUSSION}

The obtained results showed that the growth variables (plant height, branch number, fresh and dry weights, leaf number as well as leaf area) and inflorescence yield of salt-stressed pot marigold plants were decreased compared with untreated plants. Our findings are in accordance with others obtained by Moghimi and Ghavami [74] and Mbadi et al. [75] on Calendula officinalis and Hassan et al. [24] on Rosmarinus officinalis who found that the salt stress treatments seriously affected the growth and development. Nevertheless exogenously applied BABA effectively mitigated the salt stress hurtful effects and promoted the plant growth characteristics. It has been reported that BABA seed priming was found to be helpful for several plants to neutralise the adverse effects of different abiotic stresses [44].

In this concern, exogenously applied of BABA play an important role in increasing plant tolerance versus abiotic stresses like salt [53, 54]. Pretreatment of rice seeds with BABA enhanced radicle length and seedling growth under stressed conditions compared to control [76]. Salt stress usually led to drought stress, drought stress is characterised by tissues dehydration and its influence could be better evaluated by determining the RWC which signal the water cells status. In our research, a decrease in RWC was observed on exposure to salt stress. Notably, the reduction in RWC of pot marigold leaves was more retarded in BABAtreated plants (Fig. 1A).

In our study, stomatal conductance and chlorophyll content were significantly reduced due to salt stress, however, BABA seed priming treatments improved the stomatal conductance under salinity. It has been reported that salt stress significantly reduced the chlorophyll content in pot marigold [74,75]. Decreasing RWC, chlorophyll and stomatal conductance under salt stress have been documented [24,77]. It is well known that the stomatal closure of leaves is evidence to water shortage caused by salt stress. Previous studies have shown that BABA pretreatment triggers ABA accumulation, resulting in stomatal closure thus enhancing stress tolerance $[51,78]$. The baba-mediated partial closing of stomata might be responsible for maintaining such high relative water content under salt-deficit condition (Fig. 1C). Furthermore, Jisha and Puthur [32] found that BABA priming considerably improved the photosynthetic pigments in rice compared to nonprimed seeds. Improving the photosynthetic system is considered a logic reason for growth promotion that reflected in increasing the inflorescence yield of pot marigold in the current study.

Salt stress treatments increased $\mathrm{H}_{2} \mathrm{O}_{2}$ production and lipid peroxidation measured by MDA accumulation that resulted in membrane deterioration and therefore reduced $\mathrm{MSI}$. Otherwise, pot marigold plants grown under salinity stress showed an increase in both proline and antioxidant enzyme activity. On the other hand, seed priming with BABA effectively reduced the adverse effects of salt stress on the previous physiological and biochemical attributes and therefore maintained the membrane and hence increased the tolerance of pot marigold plants to salinity. MDA is well known as lipid peroxidation indicator in oxidatively stressed plants under water deficit [48]. Xu et al. [79] reported that the accumulation of MDA showed the aggravation of membrane lipid peroxidation while BABA increased proline content and reduced MDA and hence may protect the integrity of plasma membrane [32]. It is well known that salt stress activates ROS production leading to lipid peroxidation of the membrane.

The high level of $\mathrm{H}_{2} \mathrm{O}_{2}$ caused the membrane lipid peroxidation and consequently, MDA content was increased under salt stress. However, BABA seed priming can counteract the oxidative damage and protect the cell membranes [80,81]. In the current experiment, reducing the production of $\mathrm{H}_{2} \mathrm{O}_{2}$ and MDA content suggest that BABA seed priming decreased the plasma membrane damage by decreasing the production of ROS. Moreover, the accumulation of free proline is a possible 
mechanism to protect the cells against oxidative damage [82]. Proline that promoted due to BABA priming may detoxify plants through ROS scavenging [83]. The growth reduction under salt stress in the current study could be ascribed to a decrease in nutrient uptake ( $\mathrm{N}, \mathrm{P}$ and $\mathrm{K}$ ) under salt stress [24] and as a consequence, the increase of ROS level which caused lipids oxidative damage and hence increased the MAD content was observed. The enhancement in the growth of pot marigold plants raised from primed seeds could be explained by the role of BABA in improving the nitrogen metabolism through the activation of nitrate reductase that reported by Jisha and Puthur [32].
The antioxidant enzyme activities (CAT, SOD and POD) were increased in salt-stressed pot marigold plants relative to the control (Fig. 3). Improving the antioxidant system is a critical factor against oxidative stress in plants [84]. Additionally, CAT, SOD and POD enzymes are effective scavengers of ROS and play a crucial role in alleviating oxidative damage [85]. Interestingly, BABA improved the activities of CAT, SOD and POD enzymes hence reduced the $\mathrm{H}_{2} \mathrm{O}_{2}$ level leading to enhance the membrane properties. ROS Scavenging by antioxidant enzymes when exogenous BABA was applied has been previously reported $[32,81,86]$.

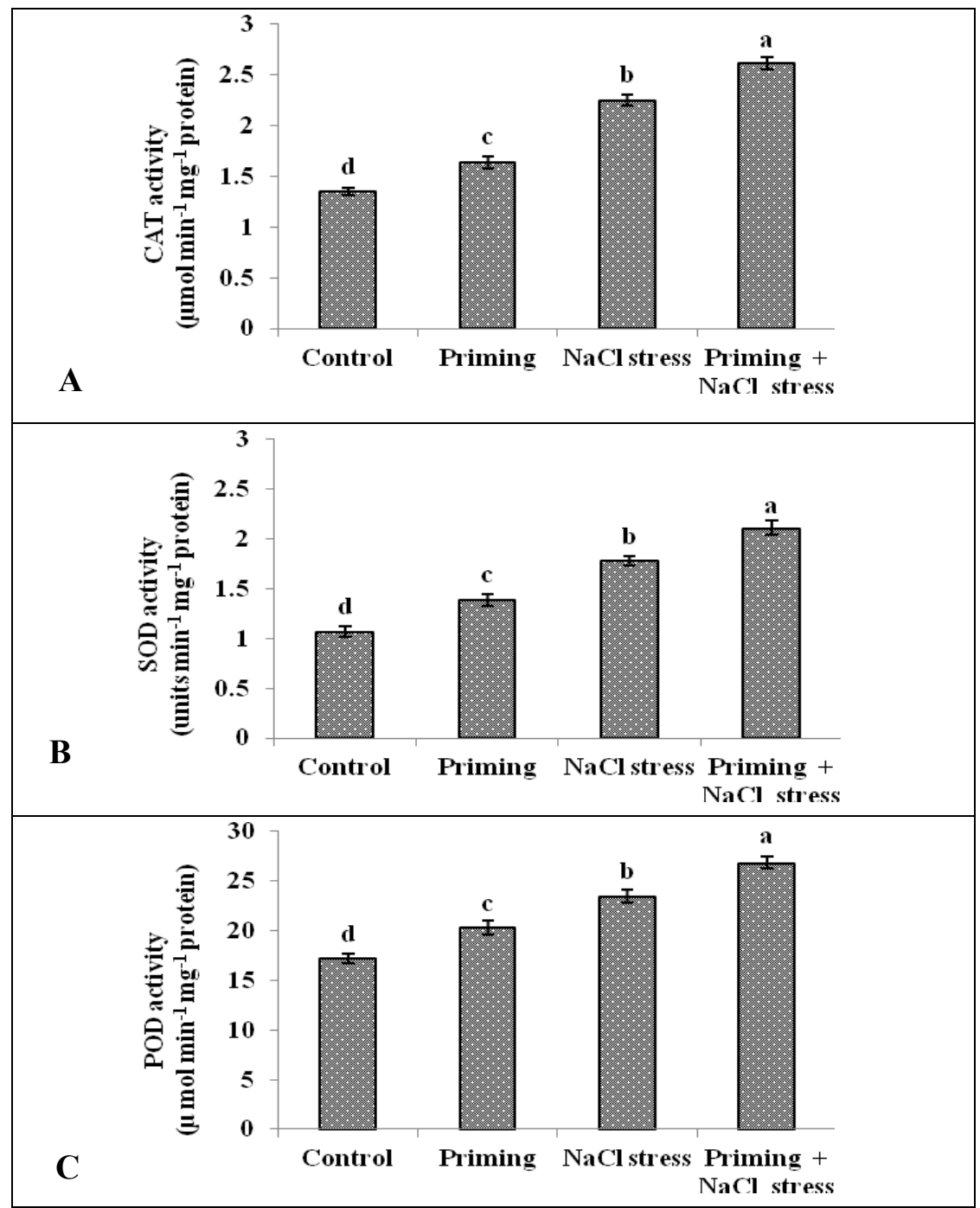

Fig. 3. Antioxidant enzyme activities (A, CAT, B, SOD and C, POD) of Calendula officinalis L. in response to $\beta$-aminobutyric acid seed priming under salt stress conditions Columns (means $\pm S E, n=8$ ) had different letters show a significant difference at $P \leq 0.05$ 


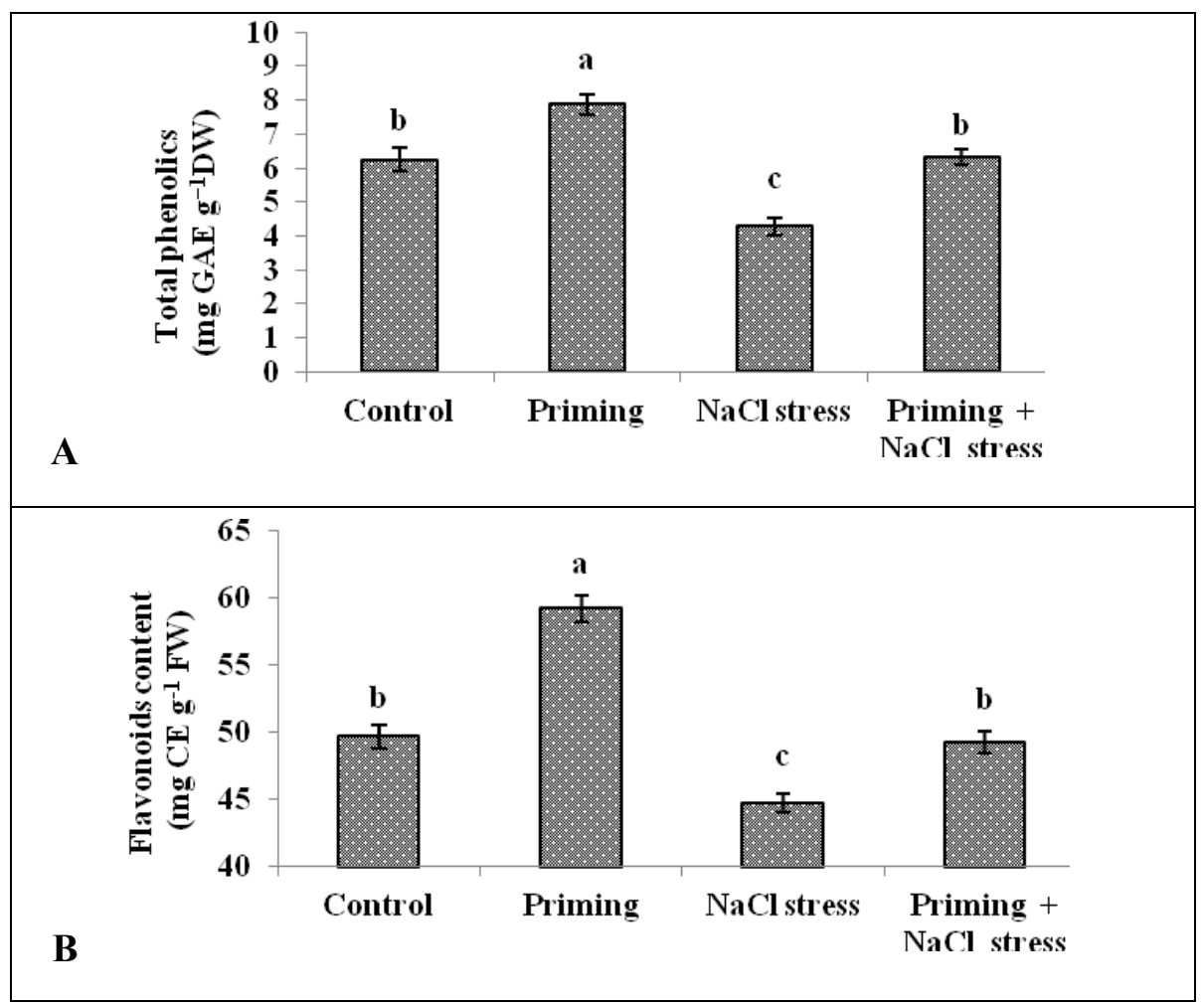

Fig. 4. Total phenolic and flavonoids contents of Calendula officinalis $L$. in response to $\beta$ aminobutyric acid seed priming under salt stress conditions

Columns (means $\pm S E, n=8$ ) had different letters show a significant difference at $P \leq 0.05$

In this study, total phenolic and flavonoids contents of Calendula officinalis L. were significantly reduced under salinity stress conditions, however, applying BABA seed priming enhanced both characters relative to the control (Fig. 4). Ashraf et al. [87] reported that phenolics had acquired much importance because of their properties of plant health promoting. Furthermore, BABA may directly/indirectly affect the metabolic processes in such a way that it enhanced the internal phenolic and flavonoid contents in pot marigold. However, the exact mechanism is unknown. Otherwise, BABA seed priming promoted the photosynthetic system that resulted in improving the photosynthetic pigments in pot marigold $[74,75]$ therefore the flavonoids content may be enhanced.

\section{CONCLUSION}

BABA seed priming improved the plant growth and development under salinity. This treatment also maintained RWC, chlorophyll content, stomatal conductance and nutrient content. Also, it also enhanced the activities of CAT, SOD and
POD enzymes as well as proline content which reduced $\mathrm{H}_{2} \mathrm{O}_{2}$ production and limited MDA accumulation, therefore, retained the membrane stability and alleviated the salt stress damage. BABA treatment increased the phenolic and flavonoids contents in plants grown under salt stress. Improving the antioxidant machinery as well as total phenolics and flavonoids may play a role in the defence system against salt stress in pot marigold. Further studies are required to support the current results and to provide information about the roles of BABA that may have for phenolics and flavonoids promotion.

\section{ACKNOWLEDGEMENTS}

This study has been supported by Taif University, KSA project No. 1-438-5751 and it is appreciated. The authors are grateful to the Agency of Taif University for graduate studies and scientific research.

\section{COMPETING INTERESTS}

Authors have declared that no competing interests exist. 


\section{REFERENCES}

1. Chakraborthy GS, Arora R, Maje C. Antidiabetic and anti-hyperlipidemic effect of hydro-alcoholic extract of Calendula officinalis. IRJP. 2010;2(1):61-65.

2. Ben-Erik VW, Michael W. Medicinal plants of the worlds. Times Edition. 2004;74.

3. Re AT, Mooney D, Antigna E, Dufour E, Bark I, Srinivasan V, Nohynek G. Application of the threshold of toxicological concern approach for the safety evaluation of calendula flower ( $C$. officinalis) petals and extracts used in cosmetic and personal care products. Food and Chemical Toxicology. 2009;47:1246-1254.

4. Della LR, Tubaro A, Sosa S, Becker H, Saar $\mathrm{S}$, Isaac $\mathrm{O}$. The role of triterpenoids in topical anti-inflammatory activity of Calendula officinalis flowers. Planta Medica. 1994;60:516-520.

5. Preethi KC, Kuttan G, Kuttan R. Antioxidant potential of Calendula officinalis flowers in vitro and in vivo. Pharmaceutical Biol. 2006;44(9):691-697.

6. lauk L, Lo-Bue AM, Milazzo I, Rapisarda A, Blandino G. Antibacterial activity of medicinal plant extracts against periodontopathic bacteria. Phytotherapy Research. 2003;17:599-604.

7. Goyal M, Mathur R. Antimicrobial effects of Calendula officinalis against human pathogenic microorganisms. Journal of Herbs and Medical Toxicity. 2011;5(1):97101.

8. Barbour E, Sharif MA, Sagherian VK, Harbe AN, Talkbouk RS, Tasheuk SN. Screening of selected indigenous plants of Lebanon for antimicrobial activity. Journal of Ethno-pharmacology. 2004;93:1-7.

9. Parente LM, Lino JRS, Tresvenzol LM, Vinaud MC, de PJR, Paulo NM. Wound healing and anti-inflammatory effect in animal models of $C$. officinalis $\mathrm{L}$. growing in Brazil. Evidence-Based Complementary and Alternative Medicine. 2012;7. Article ID: 375671.

DOI: $10.1155 / 2012 / 375671$

10. Petropoulos SA, Levizou, E, Ntatsic G, Fernandes Â, Petrotose K, Akoumianakisc K, Barrosd L, Ferreira IC. Salinity effect on nutritional value, chemical composition and bioactive compounds content of Cichorium spinosum L. Food Chemistry. 2017;214: 129-136.

11. Mansour MMF. Plasma membrane permeability as an indicator of salt tolerance in plants. Biol. Plant. 2013;57:110.

12. Afzal I, Rauf S, Barsa SMA, Murtaza G. Halopriming improves vigour, metabolism of reserves and ionic contents in wheat seedlings under salt stress. Plant Soil Environ. 2008;54:382-8.

13. Alhasnawi AN, Che Radziah $\mathrm{CMZ}$, Kadhimi AA, Isahak A, Mohamad A, Yusoff WMW. Enhancement of antioxidant enzyme activities in rice callus by ascorbic acid under salinity stress. Biol Plant. 2016;60:783-787.

14. Sharma $P$, Jha AB, Dubey RS, Pessarakli M. Reactive oxygen species, oxidative damage and antioxidative defense mechanism in plants under stressful conditions. J. Bot.; 2012.

DOI: $10.1155 / 2012 / 217037$

15. Kaya C, Ak BE, Higgs D. Response of saltstressed strawberry plants to supplementary calcium nitrate and/or potassium nitrate. J Plant Nutr. 2003;26:543-60.

16. Abdel Latef $\mathrm{AAH}, \mathrm{Abu}$ Alhmad MF, Abdelfattah KE. The possible roles of priming with zno nanoparticles in mitigation of salinity stress in lupine (Lupinus termis) plants. J Plant Growth Regul. 2017;36:60. DOI: 10.1007/s00344-016-9618-x

17. Li H, Chang J, Chen H, Wang Z, Gu X, Wei C, Zhang Y, Ma J, Yang J, Zhang X. Exogenous melatonin confers salt stress tolerance to watermelon by improving photosynthesis and redox homeostasis. Front. Plant Sci. 2017;8:295. DOI: 10.3389/fpls.2017.00295

18. Yousuf PY, Ahmad A, Ganie AH, Sareer $\mathrm{O}$, Krishnapriya $\mathrm{V}$, Aref IM, lqbal $\mathrm{M}$. Antioxidant response and proteomic modulations in Indian mustard grown under salt stress. Plant Growth Regul. 2017;81:31-50.

19. Abdul Hameed Gulzar S, Aziz I, Hussain T, Gul B, Khan AM. Effects of salinity and ascorbic acid on growth, water status and antioxidant system in a perennial halophyte. AoB Plants. 2015;7.

20. Ashraf M, Harris PJC. Potential biochemical indicators of salinity tolerance in plants. Plant Sci. 2004;166:3-16.

21. Munns R, Tester M. Mechanisms of salinity tolerance. Annu. Rev. Plant Biol. 2008;59: 651-681.

22. Kaewnaree $P$, Vichitphan $S$, Klanrit $P$, Siri B, Vichitphan K. Effect of accelerated aging process on seed quality and 
biochemical changes in sweet pepper (Capsicum annuum Linn.) seeds. BioTechnol. 2011;2:175-82.

23. Manaa A, Mimouni H, Wasti S, Gharbi E, Aschi-Smiti S, Faurobert M, Ahmed HB. Comparative proteomic analysis of tomato (Solanum lycopersicum) leaves under Salinity stress. Plant Omics J. 2013;6:268-77.

24. Hassan FAS, Morsi MM, Aljoudi NGS. Alleviating the adverse effects of salt stress in rosemary by salicylic acid treatment. Research Journal of Pharmaceutical, Biological and Chemical Sciences. 2017;8(3):1980-1995.

25. Tian L, Li X, Yang R, Gu Z. Hortic. Environ. Biotechnol. 2017;57:640.

DOI: $10.1007 / \mathrm{s} 13580-016-0140-7$

26. Weisany W, Sohrabi Y, Heidari G, Siosemardeh A, Ghassemi-Golezani K. Changes in antioxidant enzymes activity and plant performance by salinity stress and zinc application in soybean (Glycine max L.). Plant Omics J. 2012;5:60-7.

27. Gong HJ, Chen KM, Zhao ZG, Chen GC, Zhou WJ. Effects of silicon on defense of wheat against oxidative stress under drought at different developmental stages. Biol Plant. 2008;52(3):592-6.

Available:http://dx.doi.org/10.1007/s10535008-0118-0

28. Ehab Al. Seed priming to alleviate salinity stress in germinating seeds. Journal of Plant Physiology. 2016;192:38-46.

29. Hubbard M, Germida J, Vujanovic V. Fungal endophytes improve wheat seed germination under heat and drought stress. Botany. 2012;90:137-49.

Available:http://dx.doi.org/10.1139/b11-091

30. Patade VY, Maya K, Zakwan A. Seed priming mediated germination improvement and tolerance to subsequent exposure to cold and salt stress in capsicum. Res J Seed Sci. 2011;4:125-36.

31. Jisha KC, Puthur JT. Seed priming with BABA ( $\beta$-amino butyric acid): A costeffective method of abiotic stress tolerance in Vigna radiata (L.) Wilczek. Protoplasma. 2016a;253:277-289.

32. Jisha KC, Puthur JT. Seed priming with beta-amino butyric acid improves abiotic stress tolerance in rice seedlings. Rice Science. 2016b;23(5):242-254.

33. Aghbolaghi MA, Sedghi M. The effect of osmo and hormone priming on germination and seed reserve utilization of millet seeds under drought stress. J. Stress Physiol. Biochem. 2014;10(1):214-221.
34. Bagher MZ. The effect of maize priming on germination characteristics, catalase and peroxidase enzyme activity and total protein content under salt stress. Int. J. Biosci. 2014;4(2):104-112.

35. Lara TS, Lira JMS, Rodrigues AC, Rakocevic M, Alvarenga AA. Potassium nitrate priming affects the activity of nitrate reductase and antioxidant enzymes in tomato germination. J. Agric. Sci. 2014;6(2):72-80.

36. Manonmani $V$, Begum MAJ, Jayanthi, $M$. Halo priming of seeds. Res. J Seed Sci. 2014;7:1-13.

Available:http://dx.doi.org/10.3923/rjss.201 4.1.13

37. Varier A, Vari AK, Dadlani M. The sub cellular basis of seed priming. Cur. Sci. 2010;99:450-6.

38. Mahajan G, Sarlach RS, Japinder S, Gill MS. Seed priming effects on germination, growth and yield of dry direct-seeded rice. J. Crop Improv. 2011;25:409-17.

Available:http://dx.doi.org/10.1080/154275 28.2011.576381

39. Kubala S, Garnczarska M, Wojtyla Ł, Clippe A, Kosmala A, Zmie 'Nko' A, Luttse $S$, Muriel $Q$. Deciphering priming induced improvement of rapeseed (Brassica napus L.) germination through an integrated transcriptomic and proteomic approach. Plant Sci. 2015;231:94-113.

40. Chen K, Arora R. Priming memory invokes seed stress-tolerance. Environ Exp Bot. 2013;94:33-45.

Available:http://dx.doi.org/10.1016/j.envexp bot.2012.03.005

41. Das $P$, Nutan KK, Singla-Pareek SL, Pareek A. Oxidative environment and redox homeostasis in plants: dissecting out significant contribution of major cellular organelles. Front. Environ Sci. 2015;2:70.

42. Ashraf M, Foolad MR. Pre-sowing seed treatment-a shotgun approach to improve germination, plant growth, and crop yield under saline and non-saline conditions. Adv Agron. 2005;88:223-271.

Available:http://dx.doi.org/10.1016/S00652113 (05)88006-X

43. Patade VY, Sujata $B$, Suprasanna $P$. Halopriming imparts tolerance to salt and PEG induced drought stress in sugarcane. Agric. Ecosyst Environ. 2009;134:24-28.

44. Jisha KC, Vijayakumari K, Puthur JT. Seed priming for abiotic stress tolerance: An overview. Acta Physiol. Plant. 2013;35: 1381-1396. 
45. Tanou G, Fotopoulos V, Molassiotis A. Priming against environmental challenges and proteomics in plants: Update and agricultural perspectives. Frontiers in Plant Sci. 2012;3:216.

46. Bewley JD, Bradford KJ, Hilhorst HWM, Nonogaki H. Seeds physiology of development. In: Germination and Dormancy. $3^{\text {rd }}$ Ed. New York: Springer; 2013.

47. Paparella S, Araújo SS, Rossi G, Wijayasinghe M, Carbonera D, Balestrazzi A. Seed priming: State of the art and new perspectives. Plant Cell Rep. 2015;34(8): 1281-93.

48. Farooq M, Basra SMA, Khalid A, Tabassum R, Mehmood T. Nutrient homeostasis, reserves metabolism and seedling vigor as affected by seed priming in coarse rice. Can J Bot. 2006;84:1196-202.

49. Nawaz A, Amjad M, Pervez MA, Afzal I. Effect of halo priming on germination and seedling vigor of tomato. Afr. J. Agric. Res. 2011;6:3551-3559.

50. Nawaz F, Ashraf MY, Ahmad R, Waraich EA. Selenium (Se) seed priming induced growth and biochemical changes in wheat under water deficit conditions. Biol Trace Element Res. 2013;151(2):284-293.

51. Jakab G, Ton J, Flors V, Zimmerli L, Metraux JP, Mauch-Mani B. Enhancing Arabidopsis salt and drought stress tolerance by chemical priming for its abscisic acid responses. Plant Physiol. 2005;139:267-274.

52. Mayer A, Eskandari S, Grallath S, Rentsch D. AtGAT1, a high affinity transporter for $\mathrm{Y}$ aminobutyric acid in Arabidopsis thaliana. J. Biol. Chem. 2006;281:7197-7204.

53. Zimmerli L, Hou BH, Tsai CH, Jakab G, Mauch-Mani B, Somerville S. The xenobiotic beta-aminobutyric acid enhances arabidopsis thermo-tolerance. Plant J. 2008;53,144-156.

54. Vijayakumari K, Jisha KC, Puthur JT. GABA/BABA priming: A means for enhancing abiotic stress tolerance potential of plants with less energy investments on defence cache. Acta Physiol Plant. 2016;38:1-14.

55. Das A, Ray R, Mandal N, Chakrabarti K. An analysis of transcripts and enzyme profiles in drought stressed jute (Corchorus capsularis) and rice (Oryza sativa) seedlings treated with $\mathrm{CaCl}_{2}$, hydroxyapatite nano-particle and $\beta$-amino butyric acid. Plant Growth Regul. 2016;79(3):1-12.
56. Quéro A, Fliniaux O, Elboutachfaiti R, Petit $E$, Guillot $X$, Hawkins $S$, Courtois J, Mesnardr F. $\beta$-Aminobutyric acid increases drought tolerance and reorganizes solute content and water homeostasis in flax (Linum usitatissimum). Metabolomics. 2015;11:1363-1375.

57. Matthew EO, Douglas AL, Isaacs R. An inexpensive accurate method for measuring leaf area and defoliation through digital image analysis. J. Econ. Entomol. 2002;95 (6):1190-1194.

58. Weatherley PE. Studies in the water relations of the cotton plant. The field measurements of water deficit in leaves. New Phytology. 1950;49:8.

59. Sadasivam S, Manickam A. Biochemical methods for agriculture sciences. Wiley Eastern Limited. 1992;181-185.

60. Bates LS, Waldren RP, Teare ID. Rapid determination of free proline for water stress studies. Plant Soil. 1973;39:205207.

61. Patterson BD, Macrae EA, Ferguson IB. Estimation of hydrogen peroxide in plant extracts using titanium (IV). Anal. Chem. 1984;134:487-492.

62. Hodges DM, Delong JM, Forney CF, Prange RK. Improving the thiobarbituric acid reactive-substances assay for estimating lipid peroxidation in plant tissue containing anthocyanin and other interfering compounds. Planta. 1999;207: 604-611.

63. Sairam RK, Deshmukh PS, Shukla DS. Tolerance to drought and temperature stress in relation to increased antioxidant enzyme activity in wheat. J. Agron. Crop Sci. 1997;178:171-177.

64. Hassan F, Mahfouz S. Effect of 1methylcyclopropene (1-MCP) on the postharvest senescence of coriander leaves during storage and its relation to antioxidant enzyme activity. Scientia Horticulturae. 2012;141:69-75.

65. Bradford MM. A rapid and sensitive method for quantitation of micro quantities of protein utilizing the principle of proteindye binding. Anal. Biochem. 1976;72:248258.

66. Giannopolitis CN, Ries SK. Superoxide dismutase I. Occurrence in higherplants. Plant Physiol. 1977;59:309-314.

67. Clairbone A. Catalase activity. In: R. Greenwald (Ed.). Handbook of Methods for Oxygen Radical Research. CRC Press, Boca Raton, Fla. 1985;283-284. 
68. Shanon L, Kay E, Lew J. Peroxidase isozymes from horseradish roots. I. Isolation and physical properties. J. Biol. Chem. 1966;241:166-172.

69. McDonald S, Prenzler PD, Antolovich M, Robards K. Phenolic content and antioxidant activity of olive extracts. Food Chem. 2001;73:73-84.

70. Dewanto $\mathrm{V}, \mathrm{Wu} \mathrm{X}$, Adom KK, Liu RH. Thermal processing enhances the nutritional value of tomatoes by increasing total antioxidant activity. Journal of Agricultural and Food Chemistry. 2002;50:3010-3014.

71. Jackson ML. Soil chemical analysis. Fall Indian Private. Ltd. New Delhi; 1978.

72. Black CA, Evans DD, Ensminger LE. Methods of soil analysis. Agronomy J. Amer. Soc. Agron. Inc. Publ., Madison, Wisconsin, U.S.A; 1965.

73. Johnson CM, Ulrich A. Analytical methods for use in plant analysis. California Agric. Exp. Stn. Bulletin. 1959;766:44-45.

74. Moghimi SM, Ghavami SH. Effect of Zeolite and salinity on growth indices of marigold (Calendula officinalis L.). Science Journal (CSJ). 2015;36:641-644.

75. Mbadi SH, Alipour ZT, Asghari H, Kashefi B. Effect of the salinity stress and arbuscular mycorhizal fungi (AMF) on the growth and nutrition of the Marigold (Calendula officinalis). Journal of Biodiversity and Environmental Sciences (JBES). 2015;6:215-219.

76. Ziogas $V$, Tanou $G$, Belghazi $M$, Diamantidis G, Molassiotis A. Characterization of $\beta$-amino- and $y$-amino butyric acid-induced citrus seeds germination under salinity using nano LC-MS/MS analysis. Plant Cell Rep. 2017;36:787-789.

77. Hassan FS, Ali EF. Effects of salt stress on growth, antioxidant enzyme activity and some other physiological parameters in jojoba (Simmondsia chinensis (Link) Schneider] plant. Australian Journal of Crop Science. 2014;8(12):1615-1624.

78. Du YL, Wang ZY, Fan JW, Turner NC, Wang T, Li FM. $\beta$-aminobutyric acid increases abscisic acid accumulation and desiccation tolerance and decreases water use but fails to improve grain yield in two spring wheat cultivars under soil drying. J. Exp. Bot. 2012;63(13):4849-4860.

79. Xu G, Magen H, Tarchitzky J, Kafka U. Advances in chloride nutrition of plants. Adv Agron. 2000;68:97-150.

80. Ella ES, Dionisio-Sese ML, Ismail AM. Seed pre-treatment in rice reduces damage, enhances carbohydrate mobilization and improves emergence and seedling establishment under flooded conditions. AoB Plants. 2011; plr007.

81. Goswami A, Banerjee R, Raha S. Drought resistance in rice seedlings conferred by seed priming: Role of the anti-oxidant defense mechanisms. Protoplasma. 2013;250:1115-1129.

82. Olga B, Eija V, Kurt VF. Antioxidants, oxidative damage and oxygen deprivation stress: A review. Annals of Botany. 2003;91:179-194.

83. Kamiab F, Talaie A, Khezri S, Javanshah A. Exogenous application of free polyamines enhance salt tolerance of pistachio (Pistacia vera L.) seedlings. Plant Growth Regul. 2014;72:257-268.

84. Li Z, Zhou H, Peng $Y$, Zhang X, Ma X, Huang L, Yan Y. Exogenously applied spermidine improves drought tolerance in creeping bentgrass associated with changes in antioxidant defense, endogenous polyamines and phytohormones. Plant Growth Regul., 2015;76:71-82.

85. Foyer $\mathrm{CH}$, Fletcher JM. Plant antioxidants: colour me healthy. Biologist. 2001;48:115120.

86. Sharma AD, Rathore SVS, Srinivasana K, Tyagia RK. Comparison of various seed priming methods for seed germination, seedling vigour and fruit yield in okra (Abelmoschus esculentus L. Moench). Scient Hort. 2014;165:75-81.

87. Ashraf A, Sarfraz RA, Rashid MA, Mahmood A, Shahid M, Noor N. Chemical composition, antioxidant, antitumor, anticancer and cytotoxic effects of Psidium guajava leaf extracts. Pharm Biol. 2016;54: 1971-1981.

(c) 2018 Ali and Hassan; This is an Open Access article distributed under the terms of the Creative Commons Attribution License (http://creativecommons.org/licenses/by/4.0), which permits unrestricted use, distribution, and reproduction in any medium, provided the original work is properly cited.

Peer-review history:

The peer review history for this paper can be accessed here: http://www. sdiarticle3.com/review-history/44349 